\title{
Long-Term Fire Regime Estimated from Soil Charcoal in Coastal Temperate Rainforests
}

\author{
$\underline{\text { Ken Lertzman }}^{1}, \underline{\text { Daniel Gavin }}^{2}, \underline{\text { Douglas Hallett }}^{3}, \underline{\text { Linda Brubaker }}^{4}, \underline{\text { Dana Lepofsky }}^{5}$, and $\underline{\text { Rolf Mathewes }}^{6}$
}

\begin{abstract}
Coastal temperate rainforests from southeast Alaska through to southern Oregon are ecologically distinct from forests of neighboring regions, which have a drier, or more continental, climate and disturbance regimes dominated by fires. The long-term role of fire remains one of the key outstanding sources of uncertainty in the historical dynamics of the wetter and less seasonal forests that dominate the northerly two thirds of the rainforest region in British Columbia and Alaska. Here, we describe the long-term fire regime in two forests on the south coast of British Columbia by means of 244 AMS radiocarbon dates of charcoal buried in forest soils. In both forests, some sites have experienced no fire over the last 6000 years and many other sites have experienced only one or two fires during that time. Intervals between fires vary from a few centuries to several thousand years. In contrast to other conifer forests, this supports a model of forest dynamics where fires are of minor ecological importance. Instead, forest history is dominated by fine-scale processes of disturbance and recovery that maintain an ubiquitous late-successional character over the forest landscape. This has significant implications for ecosystem-based forest management and our understanding of carbon storage in forest soils.
\end{abstract}

\section{INTRODUCTION}

Coastal temperate rainforests are ecologically distinct from neighboring forests, which have a drier, or more continental, climate (Meidinger and Pojar 1991, Veblen and Alaback 1996). Despite a substantial logging history, the conifer forests of the west coast of Canada and southeast Alaska contain the most extensive examples of undeveloped and semi-natural temperate rainforest remaining globally (Kellogg 1992, MacKinnon and Vold 1998). They represent a significant pool of carbon (Waring and Franklin 1979, Harmon et al. 1986) and contain many elements of biological diversity linked to late-successional forest attributes (Hansen et al. 1991). The great longevity, size, and economic value of the trees, and the significant conservation values of the forests, have led to substantial scientific and public debate on forest conservation and management. In both Canada and the United States, an ecosystem-based management paradigm has emerged from these debates. One premise of this approach is to use an understanding of the natural disturbance processes driving the historical dynamics of the forests to help design strategies for their management and conservation (FEMAT 1993, Scientific Panel for Sustainable Forest Practices in
Clayoquot Sound 1995, British Columbia Ministry of Forests 1995, Cissel et al. 1999).

Fire plays an integral role in the ecology of most conifer forests, and is a dominant feature of the historical dynamics of most forests throughout western North America (Agee 1993). For instance, throughout its range in the American Pacific Northwest and the adjacent south coast of British Columbia, Douglas-fir (Pseudotsuga menziesii (Mirb.) Franco) is an indicator of stands where summer drought is a significant factor shaping plant communities and where fire has been a significant factor in forest dynamics, either as a result of high severity fires at longer intervals (e.g., 200-600 years) or more frequent fires of varying severity (Waring and Franklin 1979, Agee 1993, Huff 1995, Long et al. 1998).

However, in the wetter and less seasonal rainforests stretching from the south coast of British Columbia north through southeast Alaska, the role of fire remains unclear. These forests are dominated by cedars (Thuja sp.), hemlocks (Tsuga sp.), true firs (Abies sp.), and Sitka spruce (Picea sitchensis Bong. Carr.) (Veblen and Alaback 1996, Meidinger and Pojar 1991). Landscapes are dominated by old-growth

\footnotetext{
${ }^{1}$ Simon Fraser University; ${ }^{2}$ Department of Plant Biology, University of Illinois, Urbana, IL 61801, USA; ${ }^{3}$ Center for Environmental Sciences \& Quaternary Sciences Program, Northern Arizona University; ${ }^{4}$ College of Forest Resources, University of Washington, Seattle, WA 98195, USA; ${ }^{5}$ Department of Archaeology, Simon Fraser University; ${ }^{6}$ Department of Biological Sciences, Simon Fraser University
} 
forests (Scientific Panel for Sustainable Forest Practices in Clayoquot Sound 1995, Lertzman et al. 1996) and major disturbances are infrequent enough that the ages of dominant trees, often used to indicate the time since the most recent fire (TSF) in a stand (Johnson and Gutsell 1994), bear little relation to stand age. In these forests, stands without a history of human intervention are characteristically old and uneven aged (Scientific Panel for Sustainable Forest Practices in
Clayoquot Sound 1995) and often show evidence of more than one generation of trees having occurred since the last major disturbance (Lertzman and Krebs 1991). Thus, even though individual trees may be very long lived (e.g., 500 to $>1000$ years, depending on species; Pojar and MacKinnon 1994), the age of such stands essentially cannot be determined by standard methods and is often likely to be far greater than that of the oldest tree.

Fig. 1. a) Location of the detail map (below) in western North America. b) Climate diagrams for the low-elevation Clayoquot Valley (CV) and the subalpine Fraser Valley (FV), showing, for each month, total precipitation (solid line) and mean daily maximum and minimum temperatures (dashed lines). Climate data from the Clayoquot Valley were supplied by the Clayoquot Biosphere Project, Tofino, British Columbia, for the period 1993-1996 (unpublished data). Climate data representing the Fraser Valley study area are from a nearby site (Wells Creek, Mt. Baker, USA) in a similar subalpine setting (1270 m above sea level) for the period 1996-2000 (Data from Western Regional Climate Center). Note the scale change used for the precipitation axis. c) Location of study areas in southwest British Columbia. The three eastern points are for the Fraser Valley study area (FV): FL, EHC, and MBC. Color shading refers to the biogeoclimatic ecosystem classification (Meidinger and Pojar 1991) that corresponds most closely with coastal temperate rainforest. Green: hypermaritime and very wet maritime subzones of the Coastal Western Hemlock Zone; Purple: all subzones of the Mountain Hemlock Zone. Dashed contour lines are lightning isopleths (number flashes $100 \mathrm{~km}^{-2}$ year ${ }^{-1}$ ) based on data for the period 1985-1995 (British Columbia Forest Service 1997) and indicate that lighting strikes are rare for the temperate rainforest zone in coastal British Columbia.
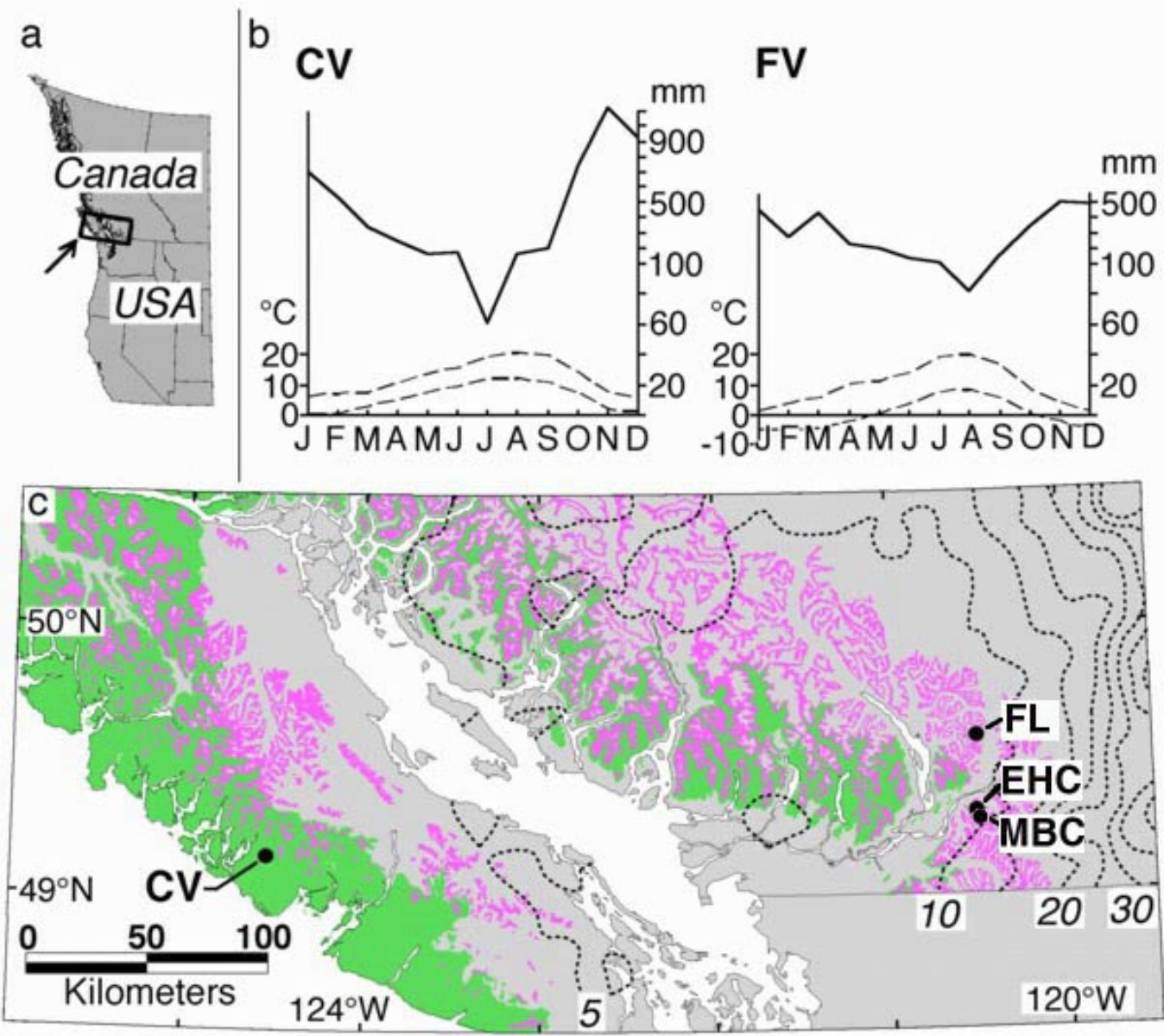
Despite the increased annual precipitation, reduced seasonality of precipitation, different stand structure, and changing species dominance, the model of episodic, stand-replacing fires developed for coastal Douglas-fir forests has largely been assumed to apply to these wetter forests. This is especially true in the forest management community, where it has been used as a rationale for large-scale, even-aged management. It is possible to find evidence of fire throughout the region: charcoal is common in the soils of rainforests in coastal British Columbia, indicating that, at some undetermined point in their past, they burned. Until now, however, no data have allowed a temporal interpretation of this charcoal. One study did suggest, based on charcoal in lake sediments, intervals between fires as great as 1700 years on the west coast of Vancouver Island (Brown and Hebda 1999).

To establish the historical role of fires in these forests, we studied the distribution and age of charcoal buried in soils (e.g., Kershaw et al. 1997). We show that charcoal can be used to date past fires in these forests and that fire is very rare in ecological time. Our data establish a reference point for analyzing modern anthropogenic disturbance regimes (e.g., logging) and indicate a potential long-term carbon sink in some soils of the region. This is the first extensive study of the long-term incidence of fire in the coastal temperate rainforests of British Columbia and represents the largest dataset of AMS radiocarbon dates of soil charcoal yet published.

\section{STUDY SITES}

We studied two areas on the south coast of British Columbia. Both occur within a broad region of transition from drier, more seasonal rainforests to wetter, less seasonal rainforests. One study area is in the Clayoquot River watershed in Clayoquot Sound on the central west coast of Vancouver Island $\left(49^{\circ} 15^{\prime} \mathrm{N}\right.$ $\left.125^{\circ} 30^{\prime} \mathrm{W}\right)$, where fire dates were obtained mainly from low-elevation sites $(<200 \mathrm{~m}$; Fig. 1). The Clayoquot Valley is characterized by river terraces below steep valley walls (40->60\%). In British Columbia's Biogeoclimatic Classification system, sites in the Clayoquot Valley study area are in very wet maritime submontane and montane variants of the Coastal Western Hemlock zone (CWHvm1 and CWHvm2; Meidinger and Pojar 1991). These forests are dominated by western hemlock (Tsuga heterophylla (Raf.) Sarg.) and western redcedar (Thuja plicata Donn ex D. Don), with Sitka spruce restricted to floodplain forests and Pacific silver fir (Abies amabilis (Doug.) ex Loud.) to moist slopes and terraces (Fig. 2). Maps, photographs, and a background on the natural history of the Clayoquot Valley may be found in the Atlas of the Clayoquot Valley (Northwest Ecosystems Institute 2000).

Fig. 2. A view of the Clayoquot River Valley showing terraced forests abutting steep valley walls. This view shows the central portion of an 8-km length of the valley comprising the study area. Sample sites were spaced ca. 200 $\mathrm{m}$ apart and were located on both terraces and lower portions of the valley walls.

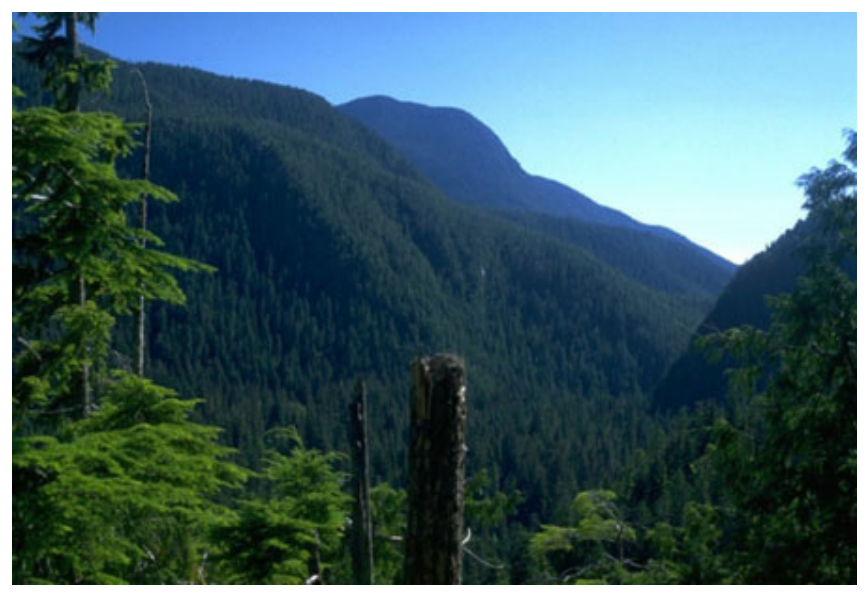

The other study area includes sites in three nearby locations in the high-elevation subalpine forests $(1100-1600 \mathrm{~m})$ of the Fraser Valley in the lower mainland of British Columbia: Mt. Barr Cirque Lake

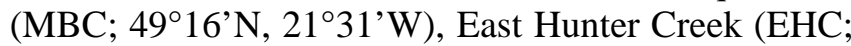
$2 \mathrm{~km}$ northwest of $\mathrm{MBC}$ ), and Frozen Lake (FL; $\left.49^{\circ} 36^{\prime} \mathrm{N}, 121^{\circ} 28^{\prime} \mathrm{W}\right)$. Fraser Valley sites are in the leeward forested variant $(\mathrm{MHmm} 2)$ or the parkland variant (MHmmp) of the Mountain Hemlock zone (MH; Meidinger and Pojar 1991). The MBC and FL sites are in the ecotone between continuous forest and subalpine parkland (a mosaic of forest and meadow vegetation), and EHC is mainly in continuous forest of mountain hemlock (Tsuga mertensiana Bong. Carr.) and Pacific silver fir (Fig. 3). Although there is some seasonality to the distribution of precipitation at our study areas, both the Fraser and Clayoquot Valley study areas typically experience more than $3000 \mathrm{~mm}$ of precipitation each year, limited summer drought, and little incidence of lightning (Fig. 1). Both study areas are typical of forest types occupying a broad geographic range in coastal British Columbia. Full botanical references can be found in Hitchcock and Cronquist (1973). 
Fig. 3. a) View of the Frozen Lakes study site in the Fraser Valley region. This illustrates the mosaic of forested and parkland locations at this study site. Subalpine meadows occur where snowpack persists into the summer. Sample sites were from meadow soils immediately adjacent to forests or from subalpine forest soils. b) The Mt. Barr Cirque study site showing extensive recent logging in the background.
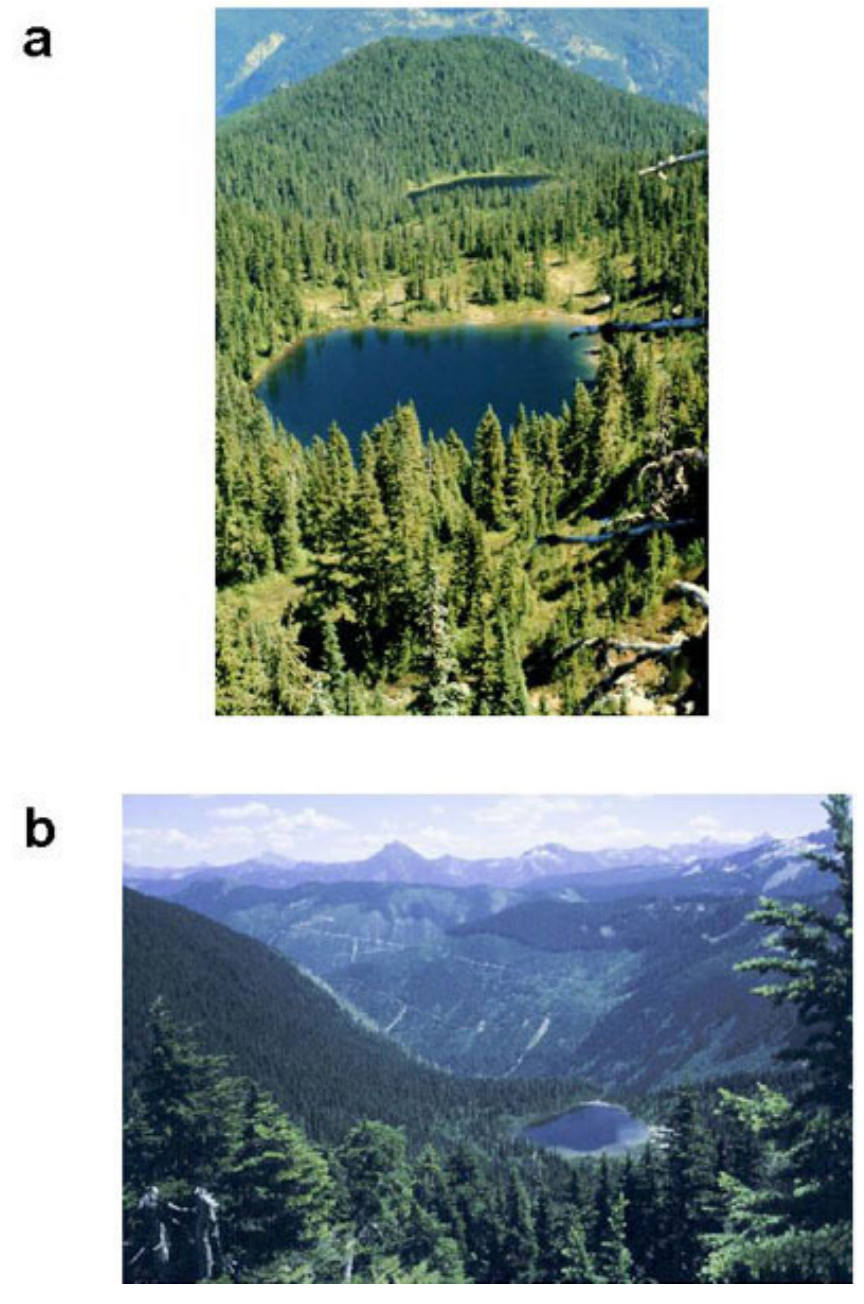

\section{METHODS}

Clayoquot Valley sampling locations were spaced evenly (ca. $200 \mathrm{~m}$ between sites) over an $8-\mathrm{km}$ stretch of pristine low-elevation forest (Gavin et al. in press. Sampling locations in the Fraser Valley sites were spaced evenly at about $100 \mathrm{~m}$ (EHC and MBC), or in three groups of closer sites (FL), with the points in a group treated together as a point sample (Hallett 2001). Sampling sites were on locally level ground that was not obviously affected by downslope soil movement. In the Clayoquot Valley, we used a steel tube to extract a soil core $5 \mathrm{~cm}$ in diameter at each sampling location. At the Fraser Valley sites, we removed $20 \times 20-\mathrm{cm}$ square monoliths of soil at each location. Soil cores and monoliths were sectioned at contiguous $1-\mathrm{cm}$ intervals for samples from the Fraser Valley and for some sites at Clayoquot Valley, and at $5-\mathrm{cm}$ intervals for the remaining Clayoquot sites. Charcoal was isolated from each 1- or 5-cm section of sample by wet sieving through $0.5-\mathrm{mm}$ mesh after soaking in $10 \% \mathrm{KOH}$ solution.

In the Clayoquot Valley, the uppermost piece of charcoal was dated at each of 83 sites; $2-5$ additional dates were obtained from 45 of these sites. At each site in the Fraser Valley, charcoal pieces were dated from each charcoal-rich stratum lying above the mineral horizons. Of the 92 monoliths analyzed from the Fraser Valley sites, we obtained dates for those with the best record of charcoal (nine at MBC, six at EHC, and 22 at FL). We do not expect this selection to introduce bias because, although it is not possible to find evidence for fires that did not occur, fires that did occur may be overlooked: thus the best local record of fire is the most appropriate to study. We dated discrete pieces of charcoal to avoid obtaining average dates from different fire events. However, if charcoal was rare, we combined two or more proximal pieces $(27 \%$ of the sites in the Clayoquot Valley and $0-5 \%$ in the Fraser Valley).

Charcoal was cleaned of extraneous humics and carbonates using acid-base-acid treatments, and AMS radiocarbon dates were obtained at the Center for Accelerator Mass Spectrometry, Lawrence Livermore National Laboratory. All dates were converted to calendar years before present (BP) using standard calibration methods (Stuiver et al. 1998). Radiocarbon dating gives an estimate of when the carbon was fixed from the atmosphere into plant tissue, not the date at which the plant was burned. The potential error caused by the difference between the radiocarbon result and the date of the fire is termed "inbuilt age" (Gavin 2001). Extensive modeling of the sources of this error suggests that the results presented here are robust with respect to errors arising from inbuilt age (Gavin 2000, Gavin 2001).

\section{RESULTS}

\section{Overall structure and age of humus layers}

Temperate rainforest soils at our higher elevation sites (primarily the Fraser Valley) are accumulations of organic matter representing much or all of the 
Holocene (last $10000{ }^{14} \mathrm{C}$ years), but at lower elevations (the Clayoquot Valley), the organic layer commonly represents several thousand years of accumulation. Forest soils at both study areas are ferro-humic podzols, with humus developed over an iron-rich, illuvial B horizon.

The Fraser Valley soils typically contain multiple, distinct, charcoal-bearing strata with basal dates in the early to middle Holocene (Fig. 4). Those at the MBC and FL sites also often contain at least one and sometimes two distinct tephra layers, providing independent dating control for the radiocarbon dates of soil charcoal: the Mazama tephra from 7825 years BP (Hallett et al. 1997) and the Bridge River tephra from 2388 years BP (Clague et al. 1995). Many sites present a remarkably undisturbed stratigraphy over their entire record (e.g., Fig. 4). This stratification indicates that we sampled charcoal representing all major fire events recorded by the soil at the high-elevation sites for the last 9000 years. Charcoal from the Fraser Valley sites provides estimates both of TSF and of the intervals between fires.

At the lower elevation Clayoquot sites, organic soils accumulated at a slightly faster rate than at the Fraser Valley sites, although organic soils older than 3000 years BP were rare (Fig. 5). In many cases, however, charcoal was restricted to a mixed mineral horizon, preventing us from determining with confidence multiple fire events at a single location and thus precluding estimates of the intervals between fires in all but a few locations (Fig. 5). This lack of stratigraphy and accumulation of charcoal in one horizon indicates that the humus in these sites has been disturbed over time by reburning and other processes. For example, root tip-ups lift soils to a vertical position and mix the organic and mineral horizons, causing the charcoal to be incorporated in the deeper, weathered mineral horizons. Thus, in contrast to the Fraser Valley high-elevation sites, a continuous record since the time of soil formation is not preserved. Despite this limitation, enough dates were obtained at each of the Clayoquot sites to ensure that the most recent fire was dated (Gavin 2000).

Fig. 4. An example of a ferro-humic podzol from the Clayoquot Valley and a mor humus soil from the MBC site in the Fraser Valley study area. Labels on the right side are calibrated radiocarbon dates of charcoal in calendar years BP $(1 \sigma$ range in parentheses). Labels on the left side of the Fraser Valley soil are dates of tephra deposits. The Mazama tephra (Hallett et al. 1997) was often visible as an orangecolored layer in humus profiles collected from late snowmelt basins. The Bridge River tephra layer (Clague et al. 1995) appeared in well-laminated humus profiles as a thin line of orange ash. The eruptions associated with these tephra desposits were very far from the study site and were not associated with local disturbance other than the deposition of the ash layer itself. The Clayoquot Valley soil is typical of many sites with an organic horizon containing much decayed wood and charcoal only located in heavily weathered mineral horizons. The Fraser Valley soil is typical of other monoliths in the study area, with abundant charcoal above the Bridge River tephra and abundant charcoal from the early Holocene below the Mazama tephra. Long fire-free intervals are apparent in many Fraser Valley monoliths.

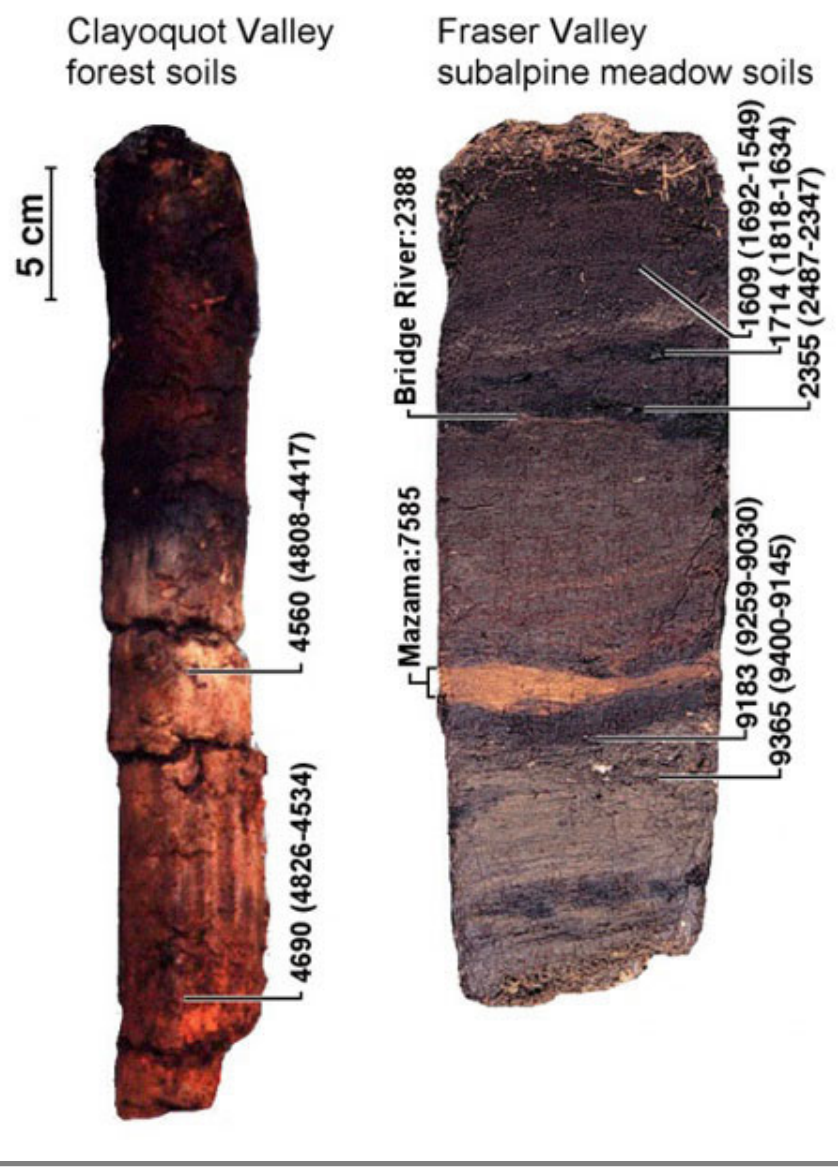

\section{Time-since-fire and fire intervals}

Sites at both study areas exhibit TSF varying from a few hundred years to many thousands of years. Some sites at each study area have not experienced fire since the early Holocene (Table 1). In the Clayoquot Valley, TSF were more widely distributed (290-12 220 calendar (cal.) years; median: 1300) than in the Fraser Valley (50-9220 cal. years; median: 1550) (Fig. 6). There is no significant difference in median TSF 
between the two study areas (two-sample randomization test, $P=0.729$ in 10000 randomizations). A larger proportion of sites have burned in the last 1000 years in the Clayoquot Valley (42\%) than in the Fraser Valley (17\%), although a larger proportion of sites in the Clayoquot Valley $(23 \%)$ than in the Fraser Valley $(6 \%)$ have not burned since the early Holocene (7000 cal. years BP). In the Clayoquot study area, where sampling was more spatially extensive, comparisons of TSF among neighboring sites indicated that fires in the late Holocene rarely extended more than $500 \mathrm{~m}$ (Gavin et al. in press).
At the Fraser Valley study sites, and in a few Clayoquot sites, dates from stratigraphically superimposed charcoal layers (Fig. 4) provide an estimate of the intervals between fires. To compensate for errors from inbuilt age, we assume that dates from the same site that were separated by less than 300 years represented wood burned in the same event. With this assumption, the Fraser Valley sites had a median fire interval of 1200 years and the Clayoquot Valley a median fire interval of 2380 years (Table 1, Fig. 6).

Table 1. Summary statistics for radiocarbon dates from the Clayoquot Valley and Fraser Valley study sites. Time-since-fire (TSF) is calculated as the youngest calibrated radiocarbon date at each site. Each sampling location in Clayoquot is treated as a separate site for estimating TSF. Because of the proximity of sampling locations at the Frozen Lakes area, we merged dates from 22 monoliths into three "sites" for calculation of TSF and fire interval statistics. Fire Interval is calculated as the time between dated charcoal samples that were separated by at least 300 years in age. This biases against finding very short fire intervals and, thus, the interval data are weaker than the TSF data, but this is necessary to avoid misidentifying fire events due to the inbuilt age error (Gavin 2001).

\section{Clayoquot Valley $\quad$ Fraser Valley}

\section{Time-since-fire (years before present)}

Number of sites

Number of radiocarbon dates

83

148

Median TSF

Minimum TSF

Maximum TSF

\section{Fire intervals} (years)

Number of sites

Number of fire intervals

Median fire interval

1300

290

12200
18

96

1550

50

9200

$\begin{array}{lll}\text { Minimum fire interval } & 450 & 300\end{array}$

$\begin{array}{lll}\text { Maximum fire interval } & 8760 & 7030\end{array}$

\section{DISCUSSION}

The maximum TSF for each study area represents nearly the entire period of time since deglaciation, which began roughly $13000 \mathrm{cal}$. years BP (Booth 1987). These are the longest documented TSF's that we are aware of for any forest worldwide. These very long fire-free periods are significant in light of regional climate and vegetation history. From 7000 to 4000 years ago, decreasing summer insolation led to a transition from a relatively warm and dry early Holocene climate to a relatively cool and moist climate (Thompson et al. 1993). This shift in climate initiated the establishment of the rainforest ecosystems, as indicated by a regional increase in species more characteristic of wetter climates and 
forest communities, such as western redcedar and western hemlock (Hebda and Matthewes 1984, Whitlock 1992). Thus, some of our sites show no evidence of ever having burned during the time that temperate rainforest has existed as a coherent combination of climate and plant communities in this area-and many sites show evidence of only one to three fires during this period. Fire is not just rare on the ecological time scale of the dynamics of populations, but is rare on the biogeographic time scale of the shaping of rainforest communities and ecosystems. This rarity of fire has supported the development of ecosystems characterized by great age, massiveness, and the ubiquity of late-seral species and structures at both stand and landscape scales.

Fig. 5. The distribution of charcoal radiocarbon dates with depth in the soil at three locations in the Clayoquot Valley (top row; presented separately for organic and mineral horizons) and in the Fraser Valley (bottom row; presented separately for three locations, all in organic soils). See Table 1 for sample sizes. Dashed lines represent least-squares regression through the origin for cases with slopes significantly $(P<0.05)$ greater than zero. Two outlier dates at East Hunter Creek (highlighted) are suspected to have resulted from redeposition caused by erosion of soils upslope. Tables of actual radiocarbon dates may be found in Gavin (2000) and Hallett (2001).

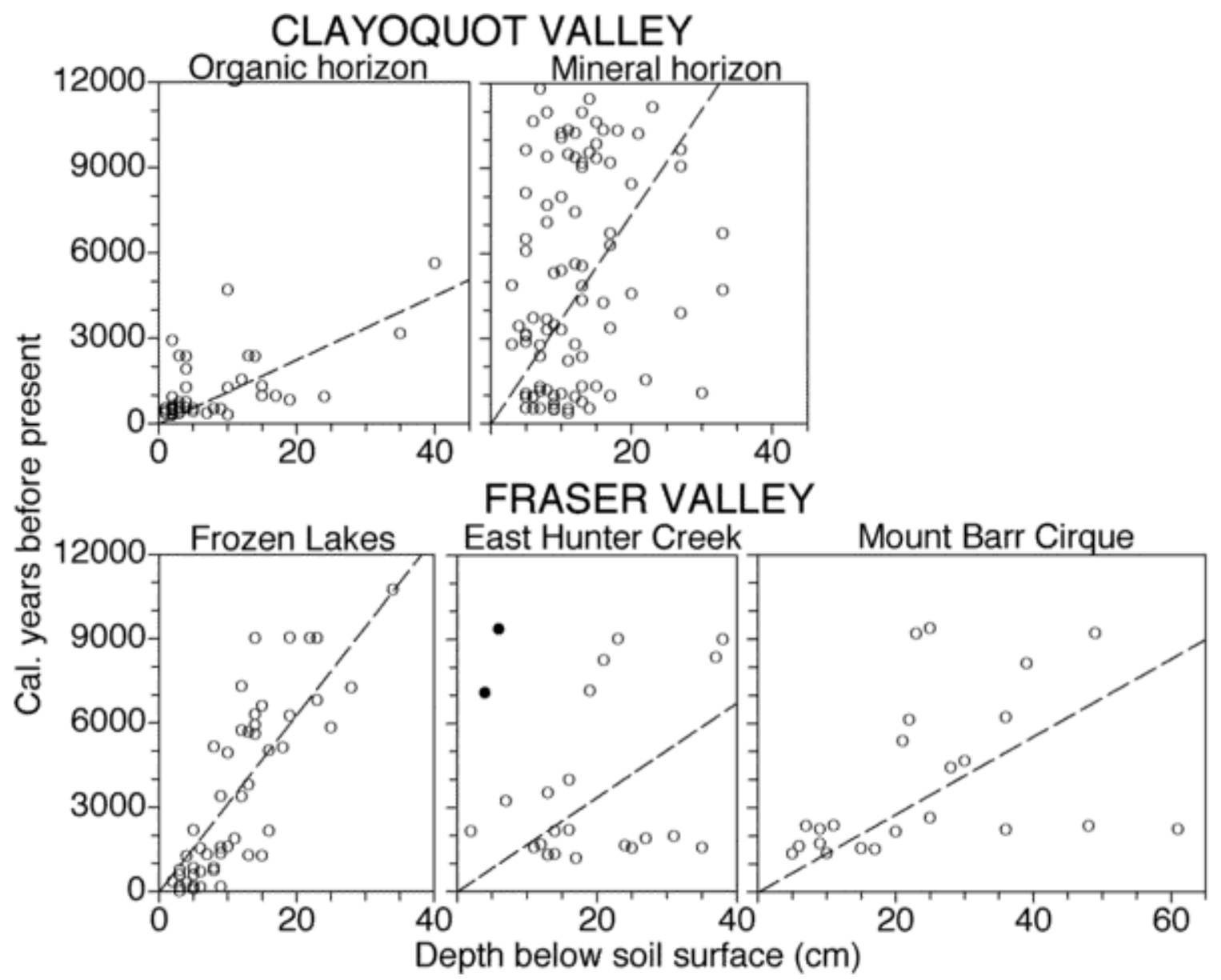

The overall summary analyses presented here mask substantial spatial and temporal variation in fire incidence. For instance, the larger variance in TSF at the Clayoquot sites reflects a wider range of topographic microsites (e.g., north- and south-facing slopes) sampled in this watershed compared with the
Fraser Valley sites, where sampling sites were mainly located on level ridgetops or the lower slopes of cirque basins. The actual frequency of fire in our study areas has varied substantially among these landscape positions (Gavin 2000, Gavin et al. in press), as well as with climatic shifts during the Holocene (Hallett 
2001; and see also Long et al. 1998), and our summary statistics cannot be assumed to be accurate estimates for any particular time during the Holocene or for any particular location on the landscape. For instance, in the Clayoquot Valley, although some sites experienced little or no fire through most of the Holocene, others burned repeatedly at less than 1000-year intervals (Gavin 2000, Gavin et al. in press). Similarly, although fire is rare overall at the Fraser Valley sites and periods without fire can extend for millennia, there are other periods with a greatly increased incidence of fire (Hallett 2001; Hallett et al. unpublished manuscript). Understanding the ecological consequences of these spatially and temporally variable fire regimes will require a more complete explanation of what drives both temporal and spatial heterogeneity in fire incidence (Lertzman et al. 1998).

Fig. 6. a) Frequency distribution of the time-since-fire at the two study areas, based on radiocarbon dates presented in Figure 3. b) Fire intervals determined from difference in radiocarbon ages; see text for explanation of interval calculation. This figure represents a composite of all fire intervals we could determine over the Holocene at each site. Adjacent sites at both study areas are separated by 100-250 m. Note that Fraser Valley sites are represented by three separate locations.

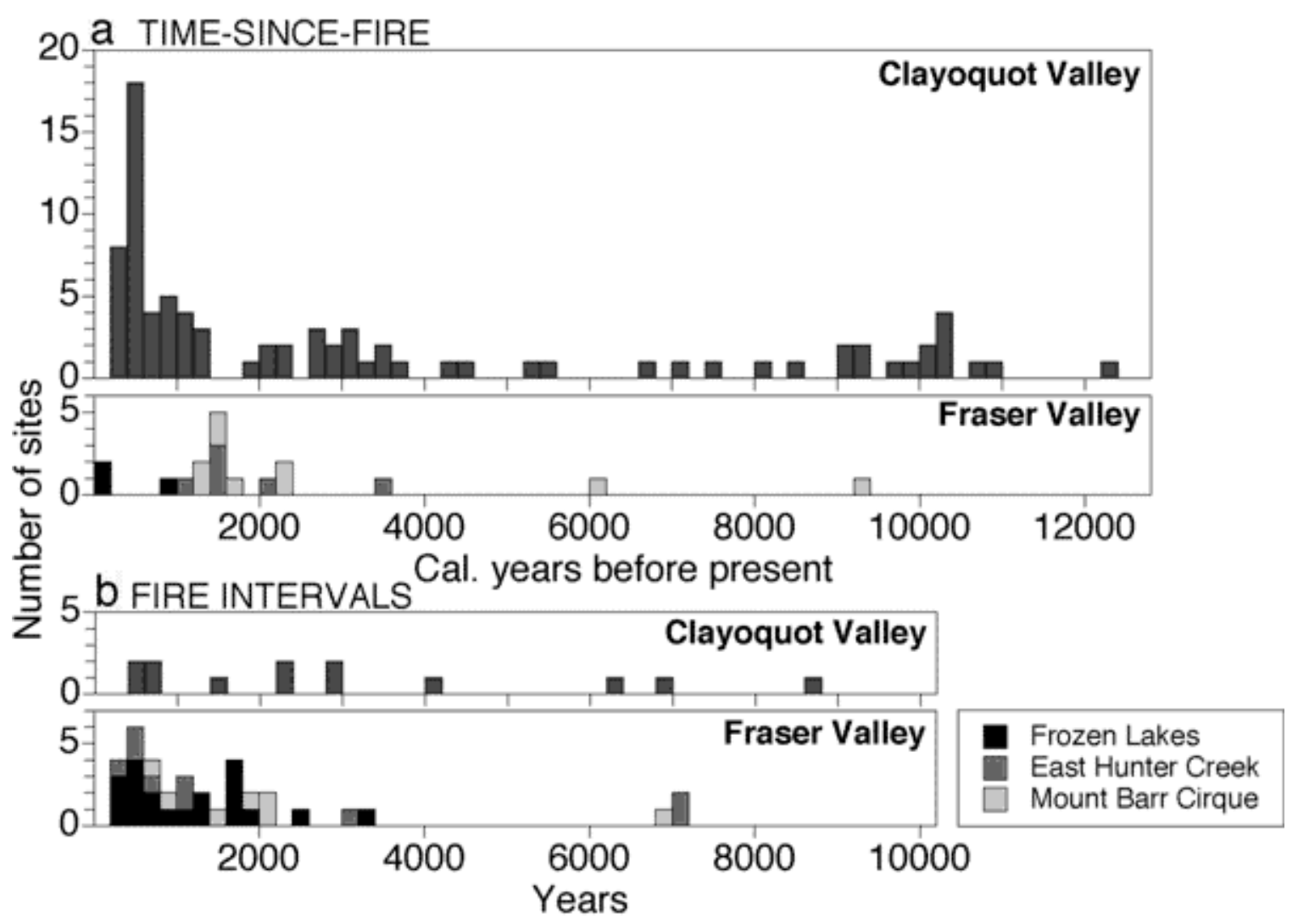

The difference in median fire interval between the Clayoquot and Fraser Valley study areas is consistent with their relative locations on a regional gradient in climate from the maritime ecosystems on the west coast of Vancouver Island to the more continentally influenced ecosystems of the eastern Fraser Valley (Fig. 1). Within $20 \mathrm{~km}$ east of the Frozen Lakes site, there is a rapid transition in climate and a shift to dry, fire-dependent forest types. Furthermore, although the Fraser Valley study area itself has a cool, wet climate and soils there remain moist throughout much of the summer because of persistent spring snowpack, it is surrounded by substantially drier forests at lower elevations in which the historical dominance of Douglas-fir indicates a substantial fire history.

In addition to their location at the edge of the temperate rainforest region climatically, the Fraser Valley sites are also on the boundary between a zone of very low incidence of lightning strikes to the west 
and one of much higher incidence to the east (Fig. 1). Lightning is more common in regions east of the Fraser Valley, where drier, more continental air masses occur. Coastal areas west of the crest of the Cascades and Coast Ranges experience little convection and thunderstorm activity because of the influence of moist and stable maritime air masses (Agee 1993). Fire weather is associated with persistent, blocking, high-pressure systems over inland western Canada (Agee 1993, Skinner et al. 1999), and changes in lightning strike densities associated with these systems are more likely to influence the Fraser Valley than Clayoquot Sound.

Although we only obtained radiocarbon dates from a restricted portion of the range of rainforest in coastal British Columbia, we expect that these results will apply to similar forests in many areas of the British Columbia coast and Southeast Alaska. The limited dating we have done at other sites on the British Columbia coast corroborates our results presented here and the patterns of soil charcoal distribution we observed in this study are repeated at a number of widely distributed sites we have examined. The geographic boundaries of the phenomenon of millennial-scale fire intervals remain to be determined where wetter forests are stratified elevationally above Douglas-fir forests, as in our Fraser Valley study area, along east-west gradients of continentality, and along north-south climatic gradients. Similarly, the applicability of our results to the interior rainforests of British Columbia remains to be evaluated. In exposed portions of the landscape, catastrophic windstorms could replace fire as a major source of stand-replacing disturbance-and in some areas of the northwest coast, large windthrow patches are a common source of stand-replacing disturbance (Kramer et al. 2001). However, in deep, narrow, valleys such as the Clayoquot Valley, major windthrow events are very rare (Lertzman et al. 1996, Veblen and Alaback 1996) and there is little evidence of large-scale windthrow events as a source of disturbance in many Mountain Hemlock zone sites (e.g., Lertzman and Krebs 1991).

In contrast to what has been described for most other northern temperate conifer forests, our results support a model of temperate rainforest dynamics where fires are of minor importance and forest history is dominated by fine-scale processes of disturbance and recovery. This distinguishes the temperate rainforests we studied from the better described, fire-dependent forests dominated by Douglas-fir to the south, and from a variety of more continental forests to the east.
Instead of a landscape exhibiting a coarse-grained mosaic of stands that originated after distinct fire events, in the absence of fire, the forest landscape is more appropriately thought of as a fine-grained mosaic of small disturbance patches originating from the gapforming mortality of only a few trees (Lertzman and Krebs 1991, Lertzman et al. 1996). This model explains the observed ubiquitous late-successional character of the pre-logging forest landscape.

\section{SPECULATION}

\section{Climate and fire regimes}

Fire regimes in these ecosystems represent an interaction between large-scale climatic drivers and local, smaller scale factors, such as aspect and fuels ("top-down" vs. "bottom-up" controls, sensu Lertzman and Fall 1998). In contrast to what is predicted for some other forests (e.g., Kasischke et al. 1995), the very long fire-free periods we observed suggest that considerable climate warming may be necessary to increase fire incidence in the coastal temperate rainforest. Under the modern climate regime, flammable conditions may occur only after periods with $>4$ weeks of no significant precipitation and in years with below-average rainfall, which recur at decadal intervals (Agee and Flewelling 1983). Climate scenarios for 2050 predict a $2-3^{\circ} \mathrm{C}$ increase in temperature and a $0-10 \%$ decrease in summer precipitation (Environment Canada 1999). Thus, increased fire hazard at sites such as the Clayoquot Valley will be primarily a function of increased summer temperature that increases the rate of fuel drying and lowers overall fuel moisture. We expect, however, that this increased drying will exert its influence most strongly on south-facing slopes, with the remainder of the landscape remaining buffered with respect to fire susceptibility because of lower levels of incident radiation (Gavin 2000, Gavin et al. in press). Extreme fire weather could render a greater portion of the landscape susceptible to fire, and we expect that the overall flammability of the landscape has changed over time with changing climatic controls (Gavin et al. in press).

At high elevations (e.g., the Fraser Valley sites), a change in precipitation from snow to rain in the fall and spring would reduce the duration of the snowpack and, thus, lengthen the periods during which forests may be susceptible to fire. Furthermore, with less snowpack limiting tree establishment, forest encroachment into meadows could result in a more 
continuous distribution of fuels. Because a smaller spring snowpack would have a compounding effect on summer fuel moisture, high-elevation sites could become disproportionately more susceptible to fire under a warmer climate. Our high-elevation sites in the Fraser Valley have experienced periods in the past with a significantly increased incidence of fire. These shifts in fire incidence are associated with variable solar activity, and peaks occur during century-scale maxima in solar irradiance (Hallett 2001; Hallett et al. unpublished manuscript). These periods represent significant temporal shifts in the local relationships between fire, climate, and ecosystem dynamics.

\section{Soil processes and charcoal taphonomy}

In addition to the results on the incidence of fire, our radiocarbon dates yield insights on soil processes, particularly rates of humus accumulation and soil disturbance. Radiocarbon-dated soil charcoal may be considered a marker deposited near the top of the soil profile at some point in the past. The fate of charcoal after this initial deposition is a function of both in situ soil-forming processes and larger-scale geomorphic processes. We realized from the start the potential for geomorphic disturbances to edit portions of the soil charcoal record; thus, we chose sites in locations with no evidence of recent debris flows and a low probability of large-scale erosion in the past. Based on our results, we can propose a model of soil charcoal taphonomy as affected processes acting at scales of 1$10 \mathrm{~m}$.

After its deposition on the soil surface, charcoal may be incorporated into subsurface soil horizons by aggrading humus, by mixing, or by a combination of these processes. Gross soil morphology and the radiocarbon data indicate that the subalpine soils we studied (Fraser Valley sites) are aggrading by means of humus accumulation, and that these profiles are rarely disturbed. This allows the soils to preserve not only distinct charcoal strata, but also tephras from two major volcanic eruptions (Fig. 2). These soils are also less likely to be consumed by fire when it occurs, as they are in wet, late-snowmelt depressions near, but not always surrounded by, continuous forest. Thus, the high-elevation soils appear characterized by a model of simple aggradation over much of the Holocene.

The low-elevation forest soils we studied also have aggrading mor humus horizons, but these horizons rarely reach ages $>3000$ years old. Furthermore, at the majority of the Clayoquot Valley sites, charcoal could only be found in the mineral horizon, and the lack of any clear age-depth trend in the mineral horizons suggests that mixing events were required to incorporate charcoal into these horizons. We suggest a two-step model of charcoal taphonomy in these forest soils. First, charcoal is deposited on the surface after a fire-this may be an exposed mineral horizon or a partially burned organic horizon. With time after deposition, the charcoal is incorporated into an aggrading mor humus horizon, with a depth proportionate to its time since deposition. Second, at some later time, charcoal may be incorporated into the mineral horizons by disturbances that mix the organic and mineral horizons. Following such a disturbance, non-charcoal organic matter is leached or bound by mineral matter in the re-establishment of the mineral horizon (Bormann et al. 1995). Burrowing animals are very rare in the soils of these forests and the most likely agent of soil disturbance is the tipping up of roots when individual trees are blown over. Thus, these radiocarbon dates suggest that soil disturbances (likely root tip-ups) recur on a site at intervals slightly less than 3000 years.

\section{Soil carbon storage}

The rarity of fires supports the notion of significant long-term carbon storage in temperate rainforests through massive accumulations of coarse woody debris and soil carbon (Waring and Franklin 1979, Harmon et al. 1986, 1990). Recent analyses indicate that carbon sink strength in forests increases as they age, primarily in the less labile soil carbon pools (Shulze et al. 2000). Given the long intervals between fires, the landscapes we studied are dominated by old forests. At low elevations in Clayoquot Sound, organic soil layers typically represent accumulations of up to about 3000 years (with older charcoal in the mineral soil; Fig. 5). The carbon content of the Clayoquot Valley soils represents a steady state between input and decomposition of organic matter that may only be reached in soils that are undisturbed for a substantial period of time (Bormann et al. 1995).

In contrast, the high-elevation organic soils of the forest-parkland ecotone (MBC and FL sites in the Fraser Valley) may represent a very long-term carbon sink subject to minimal losses as a result of decomposition under past climatic regimes. A series of dates at the contact between mineral soil and the organic layer above it suggests that modern soils began accumulating carbon in these deep humus layers about 9000 years BP (e.g., Fig. 4). Thus, these sites 
may essentially represent a nearly full Holocene carbon sink. In subalpine ecosystems, soil respiration is sensitive to temperature and will likely dominate the response of ecosystem-level carbon balance to warming (Valentini et al. 2000), potentially switching these soils from sink to source. High-elevation ecosystems in this region have proved sensitive to warming periods in the past (Brink 1959, Franklin et al. 1971, Rochefort and Peterson 1994). Although we cannot provide estimates of regional carbon storage from our data, it is clear that the significance of stored carbon in temperate rainforest soils should be assessed in the context of forest management objectives (e.g., Schulze et al. 2000) and climate warming scenarios.

\section{Ecosystem-based management}

Understanding the historical dynamics of forests is a key component of ecosystem-based approaches to forest management and conservation (FEMAT 1993, Scientific Panel for Sustainable Forest Practices in Clayoquot Sound 1995, British Columbia Ministry of Forests 1995, Cissel et al. 1999). Most research on this subject, however, has focused on fire as a primary factor shaping forest dynamics (e.g., Bergeron and Harvey 1997, Cissel et al. 1999). Our evidence suggests that the time between fires may be of an order of magnitude greater than has been assumed in some policy documents (e.g., British Columbia Ministry of Forests 1995). If we are to build credible regimes of ecosystem-based management for forests such as those we studied, novel approaches to management must be developed that consider the fine-scale disturbance and recovery processes that dominate in the absence of periodic large-scale fires (Lertzman et al. 1996). Such approaches must be multiscaled. At the stand scale, silvicultural systems must be developed that provide a high degree of temporal and spatial continuity in latesuccessional stand structures (e.g., large downed logs and snags, gaps, and diverse tree ages and sizes; Wells et al. 1998), reflecting the long periods between disturbances indicated by our data. This is not without difficulty, both engineering and silivicultural. However, the Variable Retention System currently under development in coastal British Columbia is intended to allow these kinds of stand structures and is being implemented successfully (e.g., Scientific Panel for Sustainable Forest Practices in Clayoquot Sound 1995, Kohm and Franklin 1997, Mitchell and Beese in press). At the landscape-scale, parameters of the overall management regime, such as the rate of cut, rotation length, and allocation of forest area to riparian and other late-seral reserves, must be adjusted to provide for the ubiquity of late-seral stands. Collectively, these recommendations represent a significant departure from the large-scale, even-aged management that has been traditional industrial practice in the coastal temperate rainforests of North America.

Responses to this article can be read online at: http://www.consecol.org/vol6/iss2/art5/responses/index.html.

\section{Acknowledgments:}

This research was funded by grants from Forest Renewal British Columbia administered by the Science Council of British Columbia, and the Global Forest Foundation (contribution \#GF18-2000-102). We greatly appreciate the assistance of $C$. Takahashi and A. Walton, both in the field and lab, work by G. Baptiste in the lab, and field help from B. Brett, T. Opalka, and many volunteers. The Clayoquot Biosphere Project provided logistic support in the Clayoquot Valley. We gratefully acknowledge Sto:lo Nation for permission to work in their traditional territory in the Fraser Valley and for the assistance of their representatives, especially Sonny McHalsie, Dave Schaepe, and Kevin Washbrook. Erle Nelsen provided helpful input on radiocarbon dating. We appreciate thoughtful reviews by Andy MacKinnon, Werner Kurz, David Foster, Detlef Schulze, and two anonymous reviewers.

\section{LITERATURE CITED}

Agee, J. 1993. Fire Ecology of Pacific Northwest Forests. Island Press, Washington, D. C., USA.

Agee, J. K., and R. Flewelling. 1983. A fire cycle model based on climate for the Olympic Mountains, Washington. Pages 32-37 in Proceedings of the Fire and Forest Meteorology Conference, American Meteorological Society, Boston, Massachussetts, USA.

Bergeron, Y., and B. Harvey. 1997. Basing silviculture on natural ecosystem dynamics: an approach applied to the southern boreal mixedwood forest of Quebec. Forest Ecology and Management 92:235-242.

Booth, D. B. 1987. Timing and process of deglaciation along the southern margin of the Cordilleran ice sheet. Pages 71-90 in W. F. Ruddiman, and H. E. Wright, Jr., editors. North America and Adjacent Oceans during the Last Deglaciation. Geological Society of America, Boulder, Colorado, USA.

Bormann, B. T., H. Spaltenstein, M. H. McClellan, F. C. Ugolini, K. Cromack, and S. M. Nay. 1995. Rapid soil 
development after windthrow disturbance in pristine forests. Journal of Ecology 83:747-757.

Brink, V. C. 1959. A directional change in subalpine-heath ecotone in Garibaldi Park, British Columbia. Ecology 40:10-16.

British Columbia Forest Service. 1997. Historical Lightning Database. British Columbia Ministry of Forests, Victoria, British Columbia, Canada.

British Columbia Ministry of Forests. 1995. Forest Practices Code of British Columbia: Biodiversity Guidebook. Queens Printer, Victoria, British Columbia, Canada.

Brown, K. J., and R. J Hebda. 1999. Long-term fire incidence in coastal forests of British Columbia. Northwest Science 73:41-43.

Cissel, J. H., F. J. Swanson, and P. J. Weisberg. 1999. Landscape management using historical fire regimes: Blue River, Oregon. Ecological Applications 9:1217-1231.

Clague, J. J., S. G. Evans, V. N. Rampton, and G. J. Woodsworth. 1995. Improved age estimates for the WhiteRiver and Bridge-River tephras, Western Canada. Canadian Journal of Earth Sciences 32:1172-1179.

Environment Canada. 1999. Southern British Columbia Climate Change Impact Resources. Pacific and Yukon Region, [Online] URL: http://www.pyr.ec.gc.ca/climatechange/index e.htm.

Forest Ecosystem Management Assessment Team (FEMAT). 1993. Forest Ecosystem Management: an Ecological, Economic, and Social Assessment. Report of the Forest Ecosystem Managment Assessment Team. U. S. Department of Agriculture Forest Service, Washington, D. C. USA.

Franklin, J. F., W. H. Moir, G. W. Douglas, and C. Wiberg. 1971. Invasion of subalpine meadows by trees in the Cascades Range, Washington and Oregon. Arctic and Alpine Research 3:215-224.

Gavin, D. G. 2000. Holocene Fire History of a Coastal Temperate Rain Forest, Vancouver Island, British Columbia. Dissertation, University of Washington, Seattle, Washington, USA.

Gavin, D. G. 2001. Estimation of inbuilt age in radiocarbon ages of soil charcoal for fire history studies. Radiocarbon 43:27-44.

Gavin, D. G., L. B. Brubaker, and K. P. Lertzman. In press. Holocene fire history of a coastal temperate rain forest based on soil charcoal radiocarbon dates. Ecology.

Hallett, D. J. 2001. Holocene Fire History and Climate Change in Southern British Columbia, Based on HighResolution Analyses of Sedimentary Charcoal. Dissertation,
Simon Fraser University, Burnaby, British Columbia, Canada.

Hallett, D. J., L. V. Hills, and J. J. Clague. 1997. New accelerator mass spectrometry radiocarbon ages for the Mazama tephra layer from Kootenay National Park, British Columbia, Canada. Canadian Journal of Earth Science 34:1202-1209.

Hansen, A. J., T. A. Spies, F. J. Swanson, and J. F. Ohmann. 1991. Conserving biodiversity in managed forests: lessons from natural forests. BioScience 41:382392.

Harmon, M. E., J. F. Franklin, F. J. Swanson, P. Sollins, S. V. Gregory, J. D. Lattin, N. H. Anderson, S. P. Cline, N. G. Aumen, J. R. Sedell, G. W. Lienkaempe, K. Cromack, Jr., and K. W. Cummins. 1986. Ecology of coarse woody debris in temperate ecosystems. Advances in Ecological Research 15:133-302.

Harmon, M. E., W. K. Ferrell, and J. F. Franklin. 1990. Effects on carbon storage of conversion of old-growth forests to young forests. Science 247:699-702.

Hebda, R. J., and R. W. Mathewes. 1984. Holocene history of cedar and native Indian cultures of the North American Pacific Coast. Science 225:711-713.

Hitchcock, C. L., and A. Cronquist. 1973. Flora of the Pacific Northwest. University of Washington Press, Seattle, Washington, USA.

Huff, M. H. 1995. Forest age structure and development following wildfires in the western Olympic Mountains, Washington. Ecological Applications 5:471-483.

Johnson, E. A., and S. L. Gutsell. 1994. Fire frequency models, methods and interpretations. Advances in Ecological Research 25:239-287.

Kasischke, E. S., N. L. Christensen, Jr., and B. J. Stocks.. 1995. Fire, global warming, and the carbon balance of boreal rorests. Ecological Applications 5:437-451.

Kellogg, E., Editor. 1992. Coastal Temperate Rain Forests: Ecological Characteristics, Status, and Distribution Worldwide. Ecotrust/Conservation International, Portland, Oregon, USA.

Kershaw, A. P., M. B. Bush, G. S. Hope, K.-F. Weiss, J. G. Goldammer, and R. Sanford. 1997. The contribution of humans to past biomass burning in the tropics. Pages 413442 in J. S. Clark, H. Cachier, J. G. Goldammer, and B. Stocks, editors. Sediment Records of Biomass Burning and Global Change. Springer-Verlag, Berlin Heidelberg, Germany.

Kohm, K. A., and J. F. Franklin, editors. 1997. Creating a Forestry for the $21^{\text {st }}$ Century. Island Press, Washington, D. C., USA. 
Kramer, M. G., A. J. Hansen, M. L. Taper, and E. J. Kissinger. 2001. Abiotic controls on long-term windthrow disturbance and temperate rain forest dynamics in southeast Alaska. Ecology 82:2749-2768.

Lertzman, K. P., and C. J. Krebs. 1991. Gap-phase structure of a subalpine old-growth forest. Canadian Journal of Forest Research 21:1730-1741.

Lertzman, K. P., and J. Fall. 1998. From forest stand to landscape: the impacts of disturbance. Pages 339-367 in D. Peterson and V. T. Parker, editors. Scale Issues in Ecology. Columbia University Press, New York, New York, USA.

Lertzman, K. P., J. Fall, and B. Dorner. 1998. Three kinds of heterogeneity in fire regimes: at the crossroads of fire history and landscape ecology. Northwest Science 72:423.

Lertzman, K. P., G. Sutherland, A. Inselberg, and S. Saunders. 1996. Canopy gaps and the landscape mosaic in a temperate rainforest. Ecology 77:1254-1270.

Long, C. J., C. Whitlock, P. J. Bartlein, and S. H. Millspaugh. 1998. A 9000-year fire history from the Oregon Coast Range, based on a high-resolution charcoal study. Canadian Journal of Forest Research 28:774-787.

MacKinnon, A., and T. Vold. 1998. Old-growth forests inventory for British Columbia Canada. Natural Areas Journal 18:309-318.

Meidinger, D., and J. Pojar. 1991. Ecosystems of British Columbia. British Columbia Ministry of Forests.

Mitchell, S. J., and W. J. Beese. In press. The retention system: reconciling variable retention with the principles of silvicultural systems. Forestry Chronicle.

Northwest Ecosystems Institute. 2000. Kennedy Watershed Atlas Series Volume II: Clayoquot Valley Natural History. Northwest Ecosystems Institute and Clayoquot Biosphere Trust. [Online] URL: http://www.ecosystems.bc.ca/atlas.htm.

Pojar, J., and A. MacKinnon, editors. 1994. Plants of coastal British Columbia. Lone Pine Press, Vancouver, British Columbia, Canada.

Rochefort, R. M., and Peterson, D. L. 1994. Temporal and spatial distribution of trees in subalpine meadows of Mount Rainier National Park, Washington, USA. Arctic and Alpine Research 28:52-59.

Schulze, E. D., C. Wirth, and M. Heimann. 2000. Climate change-managing forests after Kyoto. Science 289:20582059 .

Scientific Panel for Sustainable Forest Practices in Clayoquot Sound. 1995. Report 5: Sustainable Ecosystem Management in Clayoquot Sound: Planning and Practices. Cortex Consultants, Province of British Columbia.
Skinner, W. B., B. J. Stocks, D. L. Martell, B. Bonsal, and A. Shabbar. 1999. The association between circulation anomalies and the mid-troposphere and area burned by wildland fire in Canada. Theoretical and Applied Climatology 63:89-105.

Stuiver, M. , P. J. Reimer, E. Bard, J. W. Beck, G. S. Burr, K. A. Hughen, B. Kromer, G. McCormac, J. Van der Plicht, and M. Spurk. 1998. INTCAL98 radiocarbon age calibration, 24,000-0 cal BP. Radiocarbon 40:10411083.

Thompson, R. S., C. Whitlock, P. J. Bartlein, S. P. Harrison, and W. G. Spaulding. 1993. Climatic changes in the western United States since 18,000 years BP. Pages 468-513 in H. E. Wright, Jr., J. E. Kutzbach, T. Webb III, W. F. Ruddiman, F. A. Street-Perrott, and P. J. Bartlein, editors. Global Climates since the Last Glacial Maximum. University of Minnesota Press, Minneapolis, Minnesota, USA.

Valentini, R., G. G. Matteucci, A. J. Dolman, E. D. Schulze, C. Rebmann, E. J. Moors, A. Granier, P. Gross, N. O. Jensen, K. Pilegaard, A. Lindroth, A. Grelle, C. Bernhofer, T. Grunwald, M. Aubinet, R. Ceulemans, A. S. Kowalski, T. Vesala, U. Rannik, P. Berbigier, D. Loustau, J. Guomundsson, H. Thorgeirsson, A. Ibrom, K. Morgenstern, R. Clement, J. Moncrieff, L. Montagnani, S. Minerbi, and P. G. Jarvis. 2000. Respiration as the main determinant of carbon balance in European forests. Nature 404:861-865.

Veblen, T. T., and P. B. Alaback. 1996. A comparative review of forest dynamics and disturbance in the temperate rainforests of North and South America. Pages 173-213 in R. G. Lawford, P. B. Alaback, and E. Fuentes, editors. High-Latitude Rainforests and Associated Ecosystems of the West Coast of the Americas. Springer-Verlag, New York, New York, USA.

Waring, R. H., and J. F. Franklin. 1979. Evergreen coniferous forests of the Pacific Northwest. Science 204:1380-1386.

Wells, R. W., K. P. Lertzman, and S. C. Saunders. 1998. Old-growth definitions for the forests of British Columbia. Natural Areas Journal 18:280-294.

Whitlock, C. 1992. Vegetational and climatic history of the Pacific Northwest during the last 20,000 years: implications for understanding present day biodiversity. Northwest Environmental Journal 8:5-28. 